\title{
Psychological Aspects of Citizenship Characters Development
}

\author{
Luthfi Fathan Dahriyanto \\ Department of Psychology \\ Semarang State University \\ Semarang, Indonesia \\ luthfifathan@mail.unnes.ac.id
}

\begin{abstract}
Human have two modalities, namely physical and psychological. These two modalities are changing with the growth and development of the individual. As a result of these changes, cognitive, affective and psychomotor aspects of the individual progressed to maturity. Psychology explains these changes in the study of developmental psychology, which studies the growth and development of humans from birth to old age. The development of individual behaviour from infancy to old age is described thoroughly in developmental psychology, thus knowledge of developmental principles becomes a basis for making policies or rules relating to humans. These principles have long been applied in education, such as educational planning which is based on the talents, skills and intelligence of children). This predictive ability can be utilized to perform development programs that fit the stages of development. The principle of developmental psychology also affirms that the mental aspects of human beings develop in line with individual changes; to direct such changes the role of educational institutions is very important. This study seeks to find out some basic psychological modalities that are very important and play a role in citizenship characters development. Those modalities will affect whether a country will progress or fail. Subject of this study are 308 college students. Results shows that $71 \%$ of the students have a mild citizenship character, and $29 \%$ have a high citizenship character.
\end{abstract}

\section{Keywords-character; citizenship; development; psychology}

\section{INTRODUCTION}

Over the last 10 years educators and businessmen have complained about the lack of character in graduates or students. This is a common problem acknowledged by various university institutions in Indonesia. Education, especially campus is a miniature of a society. Campus has an important strategic role to prepare future generation and leaders of the nation. Furthermore, higher education institutions have constantly being the model for creating agencies of change. However many educators believe, students are highly competent academic, but the ability to develop positive character is still very low. More than 40 years ago the German engineers association stated that at least $20 \%$ of the education curriculum should be based on character development [1]. College students carry both intellectual and moral responsibility. Thus students in campus should be given an understanding of the importance of sharpening their skills when they are in college. Campus should be providing guidance in following every nonacademic activities on campus to improve character development, for example to improve thinking skills, learning skills and living skills. That students are need training to become an effective team member [2]. Since there are many graduates lacking organizational skills. Suggests that many companies need workers which have creativity, communication skills, and cultural understanding [3].

Students need to get assistance to be able to play an important role in accordance with the chosen profession. Campus is holding a strategic role to build citizenship characters. Understanding the development of character related directly to aspects of personality, morals or character. Thus the existence of character is related to the development of self.

\section{THEORETICAL BACKGROUND}

\section{A. Intellectual Capital}

Intellectual capital is a facility which has a role in finding opportunities and turning threats into challenges. In the industrial revolution 4.0 era, which signed by automatic machine and high competition, this modality is exceptionally needed in order to be competitive and survive. Many psychologists claimed that developed countries always give priority to the development of human resources, which in this case can begin by altering the mindset (mental setting) of the individual through education.

Strengthening intellectual capital is an ongoing process, as science and technology are constantly changing. To reinforce this, the alterations of activities need to be facilitated by sharing knowledge in communities and in various levels of society. This knowledge sharing activities will grow innovation that will foster creativity and work that will have beneficial impact to Indonesia.

\section{B. Social Capital}

Social capital is an important component in the citizenship characters. Social capital is defined as the ability of a person in establishing social relationships and foster relationships to support each other and work together. Therefore through this modality the individual will build synergy with the people around him. Social capital is not unconditional; the ability to respect differences and respect others is a critical success.

Gotong royong has become a valuable modality to the people of Indonesia and is something that should be developed 
and preserved. Gotong royong is the embodiment of social capital that is important in developing the environment both community and physical environment. This social modality is still commonly done in many places in Indonesia and is an example of positive social capital that needs to be maintained.

\section{Mental Capital (soft capital)}

According to Ancok mental capital is an important basis for the growing of intellectual capital and social capital [4]. Since, mental capital is characterized by trustworthiness and trust in others, being able to withstand emotion, forgiving, compassionate, sincerity, and always wanting to please others is indispensable for efforts to build a civilized and highperformance society. Soft capital is important to be a social binder and emotional damper to minimizing conflict and violence.

One form of mental capital is ability in managing emotions defined as the ability to identify, understand, use and manage emotions in life [5]. Individuals who have good emotional intelligence will be able to: understand their own emotions, be able to manage their own emotions, motivate themselves, understand the emotions of others and be able to foster social relationships.

\section{Spiritual Capital}

According to Ancok the spiritual capital is separated from the above three modalities, it emphasize the importance of human religious development efforts [4]. Many scholars believe, religion will become the guide of life in order not to become an egoistic whose orientation only concerns its own interests. Therefore, efforts to develop religion are an absolute and essential part for the growth of prosperous individual and society.

\section{METHOD}

Three hundred and six (306) university students participated in this study. Subjects are selected by faculty, organizational activity and GPA. To investigate the citizen character development of student citizenship character scale are given to subjects.

\section{RESULT AND DISCUSSION}

\section{A. Results}

It was found that most students had medium category (71.5\%) and high $(28.2 \%)$ on citizenship character. Based on student activity in the organization, it was found that there were no differences in the character of students' in terms of participation in the organization. Among activities that have the possibility to contribute to character building are conducting community service activities or working on a project in the community that is related to volunteerism, cultural diversity, contact and cooperation with students from other races and ethnicities, or having a conversation with students who have different political and social views.

\section{B. Discussion}

National character will be strong if the individual character of citizens is also well-built [6]. As an important component that determines national power, national character must be educated to the younger generation. Since, they are the future owners of this nation. Young generation did not experience the bitterness of the founders of the nation developing noble values that became the foundation for the beginning of the Indonesian nation. Without any internalization efforts and socialization of noble values or character, it is feared that the younger generation does not have a solid foundation in building this country. For this reason, they need to be given character education.

Character education is comprehensive, not only related to cognitive issues, but also contains affective and psychomotor aspects. According to Berkowitz, "character education has been demonstrated to be associated with academic motivation and aspirations, academic achievement, pro-social behavior, bonding to school, altruism and democratic values, problem solving skills, moral reasoning maturity, responsibility, respect, self-efficacy, self-control, self-esteem, social skills and trust in and respect of others" [7].

To this point, people believe that character education is only related to efforts to foster the human personality. In reality, character education is not only related to the development of the human personality, but also has a significant influence on one's academic progress. As said by Megawangi "character education not only can make a child have noble character, but also can improve his academic success" [8].

Some research results show that there is a close link between the success of character education and academic success. With character education, the school atmosphere can be more fun and conducive to effective teaching and learning processes. Children with good character are those who have high emotional and spiritual maturity, so they can manage their stress better, which in turn will increase their physical endurance. This physical resilience is suspected to contribute to one's academic achievement. The results of Novick, also provide conclusions that are not different from Megawangi's view, where character education along with social and emotional learning will help students to develop their ability to manage the tasks of daily living by learning, building relationships, solving problems live everyday, and adapt to the demands of growth and physical and spiritual development [9].

The Dough Monk in his research at Texas found that a school curriculum that invites students to interact in social activities and develop their sensitivity has had a positive impact on learning change, caring and respect for school staff as well as voluntary student involvement in humanitarian projects [10]. From the aspect of human philosophy, character education is an opportunity to complete the human personality. Character education must be understood as a human endeavor [11].

Character education is fundamental in the process of human education, not accessories education. Therefore, character education is a means of civilizing and humanizing in order to form a human personality who has balanced intellectual and 
moral abilities. Character education will create a complete human person and in turn shape the community to become more humane. As part of an education program, character education can create new creatures, namely human beings with character [12].

The substance of character education has actually been mandated by Law Number 20 of 2003 concerning the National Education System (National Education System). In Article 1 of the Act, it is stated that education is a conscious and planned effort to create an atmosphere of learning and process of learning so that students actively develop their potential to have religious spiritual strength, self-control, personality, intelligence, noble character, and the skills needed by themselves, community, nation and state. As outlined by the National Education System Law, the function of national education is to develop the capabilities and shape of national character and civilization. Meanwhile, the goal of national education is to develop the potential of students to become faithful and fearful people of God, noble, healthy, knowledgeable, capable, creative, independent, and become democratic and responsible citizens. From the sound of the National Education System Law, it appears that without affirming character education in school and college curricula, education held in Indonesia should develop the character of the nation, because it has been mandated by the law. However, because the direction of national character education is not yet clear, the government affirms the implementation of character education in school and college curricula. The government is seriously working on character education from elementary, middle and high school. The character education strategic plan is compiled until 2025, with the hope that the development of the nation's character can take place in a sustainable manner. Along with the development of other fields, it is hoped that the noble character of the nation as the center of character education can guard the Indonesian nation towards the ideals of an advanced, just and prosperous society based on Pancasila.

The nature of personality according to behavioral approach is individual act itself. Behavior is formed based on the results of all experience as an interaction between person and environment. Man begins his life by reacting to his environment and this interaction produces patterns of behavior that shape the personality. Behavior is learned when the individual interacts with the environment, through the laws of learning which are classical, operant conditioning, and imitation. Personality is a reflection of experience, the situation or the stimulus it receives. To understand the human personality, here is a brief explanation of how a behavior is shaped [13]:

1) Classical Conditioning Theory: According to this theory, human behavior is a function of stimulus. Learning behavior occurs because of the association between behavior and the environment. Learning with this association is usually called classical conditioning. Pavlov classifies the environment into two types, namely Unconditioning Stimulus (UCS) and Conditioning Stimulus (CS). UCS is an environment that naturally generates a certain response called Unconditionting Response (UCR), whereas CS does not automatically generate response for individuals, unless there is a certain conditioning. The response that occurs due to CS conditioning is called Conditioning Response (CR).

Pavlov's experiments have been used to explain the formation of human behavior. Disorders of neurotic behavior, especially anxiety disorders and phobias occur because of the association between the stimulus and the individual response. At first, the source environment is neutral for the individual, because it is conditioned along with a particular UCS, it can lead to incorrect self-adjustment behavior. In the formation of normal behavior can occur in learning diligent behavior, for example, because it is formed because of the association.

2) Theory of Operant Conditioning : The conditioning theory developed by Skinner emphasized that the environment (in the form of consequences) is very influential on the behavior that appears [14]. According to this theory, behavior is largely determined by the consequences that accompany it [14]. If the consequences are pleasurable the behavior tends to be repeated, otherwise if the consequences are not satisfying then behavior will be reduced or eliminated. From this principle it can be understood that problematic behavior can occur and is maintained by individuals among others because it has pleasant consequences in the form of rewards from the environment. The behaviors that indicate the weakening of the attitude of citizenship, for example, do not show a sense of pride in the domestic product, which is due to the fun and pride of using foreign products.

3) Theory of Imitation (Social Learning) : The basic assumption of the theory developed by Albert Bandura is that behavior can be formed through direct model observation called imitation and through an indirect observation called vicarious conditioning. Behavior that is formed by direct imitating or imitating indirectly will become strong if it gets rewarded. An example is an individual can have effective social skills after he or she encounters individuals with good social skills (through observation, exemplary and finally applied through behavior).

4) Cognitive Behavior Therapy : This approach emphasizes the interaction between the environment and personal factors (beliefs, expectations, choices, perceptions and interpretations) that affect behavior. The theory belief that man can direct his own behavior

5) Development of Mental Revolution Values : The development of strategic values of the mental revolution can be implemented in various steps:

a) Integrity (Citizenship \& Trustful) : Development of individual integrity can be implemented through cognitive learning, by way of disseminating information both directly and indirectly (through the media) to individuals and groups on the importance of civic and trustworthy behavior (not giving and taking bribes) that are part of integrity. Campaigns on the importance of having integrity should be carried out in a massive and systematic way.

b) Work Ethic (Professional, Independent, Creative) : Work ethic is the mental attitude of individuals or groups in carrying out work activities that are characterized by work 
behaviors such as professional, independent and creative. Some ways to develop work ethic is build mental attitude. In implementing these steps, it is necessary to consider the internal and external aspects.

The development of positive work ethic can be prepared by directing self-behavior. The strategy refers to self-monitoring and self-awarded rewards and punishment. It needs clear targets of what behaviors to be developed related to work ethic. For example, after a successful assignment on time then the individual reward himself.

In addition to that for external aspects, the development of work ethic can be implemented in several ways, namely: Imitative learning or social modelling, is to provide examples or models either directly or indirectly (via video, etc.). Cognitive learning is a method in the form of verbal teaching. This technique emphasizes aspects of individual cognitive change to modify individual behavior. To develop new behaviors, reward should be given after certain behaviour is developed. This can be effective since one of the factors affecting the work ethic is influenced by the economic structure, which provides incentives for hard-working individuals. Emotional learning is applied to an individual experiencing anxiety especially related to the development of work ethic. Implementation of this step is done in a relaxed situation by presenting stimuli that cause anxiety along with another enjoyable stimulus.

c) Gotong royong : Some steps that can be implemented are developing mutual help behavior, improving the behavior of mutual assistance, maintaining the behavior of gotong royong, and modifying the emotional behavior/building the mental attitude.

Since character building is very complex and multidimensional, the scope of character development targets includes the family, education unit, government, civil society, political society, business and industry, and mass media.

\section{CONCLUSION}

Universities should conduct learning activities not only through face-to-face but also by engaging in activities that encourage students to interact with people from diverse backgrounds, as well as activities that invite volunteerism and generosity to develop citizenship characters.

\section{REFERENCES}

[1] P. V. Dharmarajan, P. Rajkumar, and K. Lanka, "The significance of inculcating soft skills in students in the process of teaching hard skills," International Journal of Applied Research and Studies, vol. I, No. II, pp. 1-11, 2012.

[2] Thacker, A. Rebecca, Yost, and A. Christine, "Training students to become effective workplace team leaders," Team Performance Management: An International Journal, vol. 8, No. 3-4, pp.89-94, 2002.

[3] J. Knell, K. Oakley and D. O'Leary, "Confronting the skills paradox: maximizing human potentialin a 21 st century economy," Retrieved in August 2008, from www.demos.co.uk/publications/skillsparadoxprovocation, accessed Sep 042018.

[4] D. Ancok, Modal Sosial dan Kualitas Masyarakat. Pidato Pengukuhan Guru Besar, Semarang: Fakultas Psikologi Universitas Negeri Semarang, 2003.

[5] D. Goleman, Kecerdasan Emosional, Jakarta: PT. Gramedia Pustaka, Utama, 2007.

[6] Koellhoffer, and T. Tara, Character Education Being Fair and Honest, New York: Infobase Publishing, 2009.

[7] L. Berkowitz, Aggression: Its causes, consequences, and control, Boston: McGraw-Hill, 1993.

[8] R. Megawangi, Pendidikan Karakter Solusi Yang Tepat Untuk Membangun Bangsa, Jakarta: BP Migas dan Star Energy, 2004.

[9] Novick, Building Learning Communities with Character, Virginia: ASCD, 2002.

[10] D. Brooks, "Increasing Test Score and Character Education The Natural Connection," 2005.

[11] N. Hindarto, Pendidikan Karakter Dalam Pembelajaran Fisika Modern, Pidato Pengukuhan Guru Besar disampaikan dalam Rapat Senat Terbuka Universitas Negeri Semarang, 2010.

[12] E. Durkheim, Pendidikan Moral Suatu Studi Teori dan Aplikasi Sosiologi Pendidikan, terjemahan Lukas Ginting, Jakarta: Erlangga, 1990.

[13] G. Feist, and J. Feist, Theories of Personality, Boston: McGraw Hill, 2013.

[14] G. Corey, Teori dan Praktek Konseling dan Psikoterapi, Bandung: Rafika Aditama, 2009. 